\title{
E-Moderation Skills in Discussion Forums: Patterns of Online Interactions for Knowledge Construction
}

\author{
Vinothini Vasodavan ${ }^{1 *}$, Dorothy DeWitt ${ }^{1}$, Norlidah Alias ${ }^{1}$ and Mariani Md Noh$^{2}$ \\ ${ }^{1}$ Department of Curriculum and Instructional Technology, Faculty of Education, University Malaya, \\ Kuala Lumpur, 50603, Malaysia \\ ${ }^{2}$ Department of Educational Psychology and Counselling, Faculty of Education, University Malaya, \\ Kuala Lumpur, 50603, Malaysia
}

\begin{abstract}
Discussion forums have the potential for enabling knowledge construction during online interactions, especially when facilitated by a skilled e-moderator. Unfortunately, most e-moderators are not provided training for facilitating discussions, and hence may only summarise information and deliver factual knowledge without encouraging elaboration or reflection among the learners. Hence, this study focused on developing e-moderation skills in discussion forums by investigating the patterns of interactions among 24 students in an undergraduate course. This study employed one group pre-test and post-test experimental group design to measure student's interaction patterns after undergoing training for e-moderation. After moderating online discussion forums, a content analysis of the transcripts of the discourse in their forum

ARTICLE INFO

\section{Article history:}

Received: 1 July 2019

Accepted: 20 July 2020

Published: 25 December 2020

DOI: https://doi.org/10.47836/pjssh.28.4.30

E-mail addresses:

vino1905@gmail.com (Vinothini Vasodavan)

dorothy@um.edu.my (Dorothy DeWitt)

drnorlidah@um.edu.my (Norlidah Alias)

marianin@um.edu.my (Mariani Md Noh)

*Corresponding author

was conducted to understand the nature of the interaction patterns and the quality of the discussions. The results revealed that training had contributed to a significant increase in domains of social interaction, sharing information, egocentric elaboration, allocentric elaboration, application and transfer, coordination, and reflection. The skillset in this study can be applied by e-moderators to effectively facilitate online learning for knowledge development. It is recommended that instructors in higher
\end{abstract}

ISSN: 0128-7702

e-ISSN: 2231-8534 
education institutions be equipped with skills to scaffold students in constructing knowledge.

Keywords: Discussion forum, e-moderator, interaction pattern, knowledge-construction

\section{INTRODUCTION}

Higher education institutions are delivering more courses in the blended mode of instruction, using asynchronous and synchronous computer technologies for communication (Tseng et al., 2016). Learning Management Systems (LMS) are now being used as platforms for an ubiquitous learning experience to assign tasks and facilitate learning online (Ain et al., 2016).

One of the tools widely used for interaction in LMS is the discussion forum (Kent et al., 2016). Discussion forums can replace the interactions of a face-to-face class with interesting learning opportunities (Orooji \& Taghiyareh, 2015). While it can be used for knowledge generation, the quality of interactions within the forum depends on the task assigned and the skills of the e-moderator (DeWitt et al., 2016). The e-moderator manages the online learning environment and facilitates the interactions (Salmon, 2012). Although the role of the e-moderator is important, students at higher education institutions are not exposed to e-moderating skills.

The Malaysian Ministry of Higher Education (MOHE) emphasizes on online learning as an integral part in higher education for lifelong learning and recommends $70 \%$ of programmes utilise blended learning for the transformation of undergraduate courses (MOHE, 2015).

Blended learning is seen as the impetus for innovation. Hence, having a framework for developing e-moderation skills to facilitate interactivity in discussion forums in the higher education is important. A comprehensive e-moderator training program can improve the nature and quality of e-moderation (Ghadirian et al., 2016).

The Five-Stage Model of Online Teaching and Learning (Salmon, 2012) dives the e-moderation process in the following stages: access and motivation, online socialization, information exchange, knowledge construction, and development. Each stage requires the e-moderator's involvement and commitment, from monitoring the course participants' actions and contributions to intervening to give advice and guidance (Salmon, 2013; Schökler, 2015).

E-moderator skills such as understanding the online processes, having content expertise, suitable personal characteristics and technical and online communication skills are needed for competency (Salmon, 2013). In addition, $\mathrm{Ng}$ et al. (2009) developed e-moderation techniques which could contribute to sustaining discussions: thanking others, clarifying/elaborating, setting new directions, considering others' ideas, asking open-ended questions, and encouraging contribution. E-moderators should also acquire organizational, intellectual, social, technological, and 
pedagogical skills (Sallán et al., 2010). In addition, Smet et al. (2008) also stated that e-moderators needed to be motivators, informers, and had knowledge constructor skills in an online environment. .

However, most e-moderators only summarize information and do not elaborate or encourage reflection, leading to the delivery rather than development of knowledge as students' only focus on factual knowledge (Roscoe \& Chi, 2007; Schökler, 2015). Hence, e-moderators need to be equipped with the skills to support reflective knowledge-building in online learning environments.

Previous research have focused on discussion forums as a writing tool (Biasutti, 2017; Burhan-Horasanl1 \& Ortaçtepe, 2016) on thread growth patterns (Ghadirian et al., 2016; Kent et al., 2016; Park, 2015), the role of instructors (Cho \& Tobias, 2016; Ertmer \& Koehler, 2015; Hew, 2015), patterns of interactivity among students (Hou et al., 2015; Marbouti, 2012; Park, 2015; Wei et al., 2015) and the knowledge building process (Lai, 2015). Some studies investigated the use of collaborative tools for discussion such as wikis (DeWitt et al., 2014), interactive walls, Padlet (DeWitt \& Koh, 2020), and resources such as e-books (Noor et al., 2015).

There has not been much research done on developing skills among e-moderators especially among undergraduates in Malaysia. Hence, this study investigates the difference in the patterns of interactions in a discussion forum before and after e-moderation training among undergraduates. It is important to measure the patterns of interactions as this would indicate the quality of the online discussions. The research questions are:

1. What are the patterns of students' interactions in the discussion forum without any e-moderation?

2. What are the patterns of students' interactions in the discussion forum after training for e-moderation was given?

3. Are there any significant differences in the students' interaction patterns before and after the training for e-moderation?

\section{SOCIAL CONSTRUCTIVIST THEORY}

Learning occurs through collaboration when knowledge, skills, and attitudes arising from group interactions develop the social experiences among students (Fu \& Hwang, 2018).

Social interaction and culture during collaboration in authentic contexts, such as discussion forums, encourage learning with peers and instructors (Lemke, 2001; Vygotsky, 1978).

Interactions contribute to the exchange of knowledge among peers. However, knowledge exchange alone is insufficient as students need to combine their existing knowledge with new information to create new knowledge (Xie \& Ke, 2011). Deep learning and conceptual changes happen during discussion and argumentation (Xie \& Ke, 2011; Yang, 2016). 
Hence, higher mental functions (attention, sensation, perception, and memory) using mediator tools and signs (spoken and written words) enable the students to advance cognitively within the Zone of Proximal Development (ZPD) (Lemke, 2001; So \& Brush, 2008; Wertsch, 1998). Hence, interaction with more capable peers and suitable learning tasks can improve the ZPD (De Wever et al., 2010).

Cultural tools such as discussion forums can be used to internalize for higher thinking skills during interactions to be personally meaningful for students (Bruner, 1966; Brunings et al., 1990; Vygotsky, 1978).

\section{e-Moderation in Discussion Forums}

Discussion forums normally have a textbased, topic-centred interface where students can explicitly express their thoughts (Hou et al., 2015). The forum, available 24-hours-a-day 7-days-a-week regardless of geographical location, makes it convenient to access (Kent et al., 2016; Ng et al., 2009). Students who are physically isolated in online classes face obstacles in learning. Hence, interactions in discussion forums help students feel connected (Xi \& $\mathrm{Ke}, 2011$ ). Forums creates opportunities to enhance students' learning through collaboration (Hew \& Cheung, 2013; Kent et al., 2016).

There is equal opportunity to participate in discussions and create collective knowledge when sharing, elaborating, and exchanging ideas (Cho \& Tobias, 2016; Kim et al., 2016; Yang, 2016). Social interaction enhances learning (Biasutti, 2015; Hou et al., 2015) as students interact to construct shared experiences and understanding of the world (Carceller et al., 2015; Jones \& Ryan, 2014).

Although there are many benefits of discussion forums, it can only be optimized if students participate, interact and invest considerable mental effort in the learning activities (Asterhan \& Schwarz, 2010; Kent et al., 2016).

Unfortunately, students have difficulty in sustaining discussions. The computerconferencing interface which typically concentrates more on recent postings and less on the older messages impedes discussions (Chan et al., 2009). Other issues are inappropriate behaviour of the participants (Hewitt, 2003), design of the discussion topic (Guzdial \& Turns, 2000), and students characteristics (Xie, 2013; Xie \& Ke, 2011).

Hence, a skilled moderator can encourage participation, and foster interactions in an online discussion forum (Chan et al., 2009; Ng et al., 2009; Hew, 2015). Salmon (2012) stated 'a moderator is a person who presides over a meeting, electronic meeting or conferences with a wider range of expertise' (p. 3). The moderator requires skills in keeping the discussion on track (Martinho et al., 2014), giving encouragement (Martinho et al., 2014; Sloan, 2015; Xie \& Ke, 2011), helping students overcome technical difficulties support (Salmon, 2013; Xie \& Ke, 2011) and establishing ground rules (Yeh \& Lahman, 2007). The moderator needs to know psychology and use problem-centric, 
curiosity-arousing words when initiating discussions ( $\mathrm{Ng}$ et al., 2009), and be able to draw students' attention to opposing perspectives (Yeh \& Lahman, 2007).

\section{Salmon's Five Stage Model}

The Five Stage Model has a structured developmental process and can be used across different education levels for both online and blended learning (Salmon, 2002, 2012; Schökler, 2015). The role and competencies e-moderators require are specified and can be used to design a training module to build expertise (Salmon, 2012; Yang et al., 2012). Stage one, emphasizes access to the LMS for working remotely and motivation for learning as e-moderators need to welcome students and provide support. Stage 2 is familiarization with the new online environment as one builds a new online identity and forms relationships within the group. E-moderators monitor the discussion and ensure students' comfort.

Stage 3 is access to information. Information exchange occurs freely among group members as they share their personal experiences and co-operate to achieve common goals. E-moderators guide the discussion, encourage contributions, highlighting and summarizing discussions to ensure continuity.

Stage 4 is synthesis of knowledge. Students exchange knowledge with their peers and synthesize the knowledge. E-moderators support the knowledge construction process and encourage students to widen their viewpoints and appreciate differing perspectives. Stage 5 is reflection and self-evaluation of their learning and peers' thought process. Students integrate their online experiences and begin the knowledge-building process (Koh et al., 2014). E-moderators facilitate the process by giving constructive feedback and allow students to take responsibility for their learning.

Different e-moderation skills are required at each stage as the interactivity and activity differs. The final stage requires more self-regulated and individual learning experiences.

\section{Interaction Patterns in Online Learning Interaction Model}

The Online Learning Interaction Model analysis scheme is a framework for identifying patterns of interactions in a discussion forum. There are three domains: social interaction, knowledge construction, and regulation of learning, and several subdomains: sharing information, egocentric elaboration, allocentric elaboration, application and transfer and coordination, reflection, and technical issues (Xie \& Ke, 2011). Social interaction is essential to ensure knowledge creation occurs at the later stages (DeWitt et al., 2014). Sharing greetings and integrating emotions ensures students' engagement and motivation (Xie, 2013).

Knowledge construction begins occurs when students construct new knowledge after receiving input from peers (De Wever et al., 2006; Smet et al., 2010; Weinberger et al., 2007). Activities such as discussions and projects encourage different 
viewpoints (Hou \& Wu, 2011) while social interactions encourages peer learning (Hou et al., 2015). Students express their own personal experiences, conveying their newly constructed knowledge among the community, making learning meaningful in egocentric elaboration (Sun et al., 2018; Xie \& Ke, 2011). Allocentric elaboration processes enable students to develop critical thinking skills by synthesising and developing arguments based on their peers' comments or ideas (Xie \& Ke, 2011). Students are able to compare multiple perspectives as they interpret and reorganize the information (Gašević et al., 2015; Kent et al., 2016; Xie \& Ke, 2011).

Elaboration processes enable students to integrate newly constructed knowledge through the application and transfer of knowledge in higher-level cognitive interactions in the discussion forums (Gunawardena et al., 1997; Xie \& Ke, 2011). Students who are more self-regulated, reflect upon their own learning, and facilitation in the form of technical and managerial skills are important during this learning process (Xie \& Ke, 2011; Zumbrunn et al., 2011).

The Online Learning Interaction Model is a comprehensive analytical framework for examining students' learning in online discussions as compared to other coding systems (Gunawardena et al., 1997; Newman et al., 1995; Schellens \& Valcke, 2006).

\section{METHOD}

\section{Design of the Study}

A quasi-experimental design was used in this study as random selection and assignment of participants to control and experimental groups was not possible (Cohen et al., 2011). An experimental intervention where training for e-moderation $(X)$ was introduced and online learning interaction patterns before $\left(O_{1}\right)$ and after the intervention $\left(O_{2}\right)$ was measured. The difference between prescores and post-scores contributed to the effect of the intervention.

\section{Sample}

The sample was 24 first-year undergraduate students in their first semester enrolled in a counselling course at a public higher education institution. There were 19 females (79.2\%) and 5 males (20.8\%) volunteers aged between $20(96.0 \%)$ and 21 (4.0\%) years. The students were digital natives who used social microblogs (e.g. Facebook). However, they did not have any exposure to using discussion forums for learning.

\section{Procedure}

The study was conducted over five weeks. During the first week, the students participated in the first set of forums on "Cyberbullying and Online Predators". The students explored the discussion forum platform and continued the discussions online for a week. In the second week, e-moderation training was conducted over a period of two weeks where students were briefed face-to-face on the LMS to familiarize with the learning platform as they had no prior experience with the concept of e-moderation. The expectations on the quality of discussions shared the five- 
step e-moderation model. The e-moderator's role was scripted and modelled (Salmon 2002; 2012; Ng et al., 2009; Thormann, et al., 2013). A mock discussion forum with groups of six members, was set-up for practice as students took turns being the e-moderator.

On completion of the training, students were assigned to discuss on "ICT Usage in the Field of Counselling". Students would be randomly assigned as e-moderator and take turns to manage discussions over three weeks. Students posted their ideas in the discussion forum while the instructors supported when necessary.

\section{DATA COLLECTION AND ANALYSIS}

A content analysis of the transcripts of the discussion in the 6 forum groups was conducted to understand the nature of the interaction and the quality of the discussions (Xie \& Ke, 2011). Individual interaction patterns were also measured based on the frequency of elements in a domain. A minimum score of 1 was given the elements were rarely demonstrated and a maximum of 4 when frequently demonstrated. The scoring rubric was validated by two content experts who had 5 to 10 years of experience in teaching with online collaborative tools. Pre and post mean scores for each domain were used for the analysis. In order to ensure the consistency of the content analysis, the content was blind-coded by two researchers independently. The inter-rater reliability Cohen' Kappa (.90) was acceptable (Viera $\&$ Garrett, 2005). Any differences in coding were moderated for agreement.

\section{RESULTS AND DISCUSSION}

\section{Patterns of Students' Interactions in the Discussion Forum Without e- Moderation}

After a week, the students had generated a total of 213 posts which were classified according to the codes (see Table 1). Example of quotes identified with pseudonyms, are presented to highlight the pattern of student interaction. The highest number of posts was on sharing information (K1) (67 posts, 31.4\%) probably because students could easily add factual content through internet search. There was no opinion or questions raised throughout the posting, as in the examples:

Online predators are criminals using the Internet to steal personal information or find prey. They are involved in crimes including identity theft, extortion, kidnapping, and sexual abuse of children [May:11-13]

The next highest domain was social interaction (S) (66 posts, 30.9\%) where greetings were exchanged without evidence emotions as in the example:

Peace be upon you...Kids who are cyberbullied are more likely to.... [Yue:1-2]

A few students (40 posts, 18.7\%) elaborated on points and shared knowledge (K2) without evidence of peers asking for explanations or clarification, example: 
As a counsellor, I think these two acts (Cyberbullying and Online Predators) are serious and should be controlled. This is because people should be more alert on what they are doing and don't shareanything which will harm you! [Joane:1015]

Around $12.2 \%$ (26 posts) reflected team collaboration (L1). Only new postings were responded to by peers and the older messages were ignored as students tended to forget previous postings and seldom extended the discussion. No summary of previous discussions was done.

There was little on K3, compared and synthesized or provided judgment on peers' multiple perspectives $(4.69 \%, 10$ posts). Students merely agreed on information provided by others without elaboration. There was no comparisons of ideas against peers' perspectives as in the example:

I agree with what been shared by others on cyberbully and online predators [Rose:6-7]

Similarly, for students evaluating their own learning (L2), only $1.41 \%$ (4 posts) reflected students' understanding of the topic discussed, example:

Thank you for the complete information. Before this, Imight not be able to visualize clearly the issue of cyberbullying and online predators [Wein:10-11]

No evidence of interaction was found in two domains of K4 (application and transfer) and L3 (technical issues) of students applying new knowledge for future or hypothetical scenarios and students questioning on technological problems or assignment clarification, respectively.

Hence, before e-moderation, there were fewer students' posts. There were more posts on $\mathrm{K} 1$ and $\mathrm{S}$, with some $\mathrm{K} 2$, followed by L1. There was very little on the higher levels of knowledge construction (K3 and K4) and self-evaluation and self-regulation of learning (L2 and L3).

\section{Patterns of Students' Interactions in the Discussion Forum After Training for e-Moderation}

After three weeks on the discussion forums, students generated a total of 323 posts according to the different domains (see Table 2).

Students continued to have social interactions (S) $(26.9 \%, 87$ posts $)$ and shared information (K1) $(26.6 \%, 86$ posts). Students also appreciated and confirmed contributions, using humour and emoticons to display their feelings and also asking questions. Team collaboration (L1) had increased (17.6\%, 57 posts) as the e-moderator coordinated the discussion, highlighting relevant contributions of passive participants.

Students not only elaborated their own points/arguments and concepts in detail but also used examples from personal experience when prompted by the moderator for $\mathrm{K} 2$ (17.0\%, 55 posts). Besides, peers also asked for explanations and clarification. Students demonstrated more effort in contributing and accommodating peer perspective 
Table 1

Distribution of domains of interactions without e-moderation in groups

\begin{tabular}{lllllllll}
\hline & $\mathrm{S}$ & $\mathrm{K} 1$ & $\mathrm{~K} 2$ & $\mathrm{~K} 3$ & $\mathrm{~K} 4$ & $\mathrm{~L} 1$ & $\mathrm{~L} 2$ & $\mathrm{~L} 3$ \\
\hline Group 1 & 10 & 11 & 5 & 1 & 0 & 5 & 2 & 0 \\
Group 2 & 12 & 12 & 8 & 2 & 0 & 0 & 0 & 0 \\
Group 3 & 13 & 10 & 7 & 3 & 0 & 2 & 1 & 0 \\
Group 4 & 13 & 11 & 6 & 1 & 0 & 11 & 0 & 0 \\
Group 5 & 10 & 16 & 7 & 2 & 0 & 4 & 1 & 0 \\
Group 6 & 8 & 7 & 7 & 1 & 0 & 4 & 0 & 0 \\
Total of posting & 66 & 67 & 40 & 10 & 0 & 26 & 4 & 0 \\
Percentage (\%) & 30.99 & 31.46 & 18.78 & 4.69 & 0.00 & 12.21 & 1.41 & 0.00 \\
Mean & 11.00 & 11.17 & 6.67 & 1.67 & 0.00 & 4.33 & 0.67 & 0.00 \\
SD & 2.00 & 2.93 & 1.03 & 0.82 & 0.00 & 3.72 & 0.82 & 0.00 \\
\hline
\end{tabular}

Note: Domains: Social Interaction (S), Sharing information (K1), Egocentric elaboration (K2), Allocentric elaboration (K3), Application and transfer (K4), Coordination (L1), Reflection (L2), Technical issues (L3)

Table 2

Distribution of domains of interactions after e-moderation in training in groups

\begin{tabular}{lllllllll}
\hline & $\mathrm{S}$ & $\mathrm{K} 1$ & $\mathrm{~K} 2$ & $\mathrm{~K} 3$ & $\mathrm{~K} 4$ & $\mathrm{~L} 1$ & $\mathrm{~L} 2$ & $\mathrm{~L} 3$ \\
\hline Group 1 & 21 & 15 & 14 & 4 & 1 & 8 & 1 & 0 \\
Group 2 & 18 & 9 & 6 & 8 & 1 & 8 & 1 & 0 \\
Group 3 & 11 & 13 & 7 & 2 & 4 & 10 & 0 & 0 \\
Group 4 & 8 & 15 & 9 & 7 & 1 & 9 & 2 & 0 \\
Group 5 & 17 & 13 & 10 & 2 & 1 & 14 & 1 & 0 \\
Group 6 & 12 & 21 & 9 & 0 & 0 & 8 & 2 & 0 \\
Total posting & 87 & 86 & 55 & 23 & 8 & 57 & 7 & 0 \\
Percentage (\%) & 26.93 & 26.63 & 17.03 & 7.12 & 2.48 & 17.65 & 2.17 & 0.00 \\
Mean & 14.50 & 14.33 & 9.17 & 3.83 & 1.33 & 9.50 & 1.17 & 0.00 \\
SD & 4.93 & 3.93 & 2.79 & 3.13 & 1.37 & 2.35 & 0.75 & 0.00 \\
\hline
\end{tabular}

Note: Domains: Social Interaction (S), Sharing information (K1), Egocentric elaboration (K2), Allocentric elaboration (K3), Application and transfer (K4), Coordination (L1), Reflection (L2), Technical issues (L3) 
through synthesising and elaborations (K3) $(7.12 \%, 23$ posts) as the e-moderator asked for summaries, content explanations, and clarification, rather than just agreeing or disagreeing with the comments.

The application and transfer domain (K4) had increased ( $2 \%, 8$ posts) after the e-moderator played devil's advocate and invited the students for further reflection. Students demonstrated their understanding of the topic by integrating newly learned knowledge with their prior experience.

Students evaluated their own learning during the discussions (L2) (2.17\%, 7 posts) more frequently when the e-moderator provided constructive feedback on their sharing but no evidence of interactions on technological problems (L3). The e-moderator skills and examples generated from the transcripts are in Table 3.

After the e-moderation training, the number of posts had increased (see Table 2). There was more evidence of higher order thinking with attempts in evaluating others' discussion posts and providing judgment, and more application and transfer of learning, self-evaluation and self-regulation of learning.

Table 3

Examples of E-moderator skills from the interactions in the discussion forum

\begin{tabular}{|c|c|c|}
\hline Domains & Skills & Examples \\
\hline \multirow[t]{5}{*}{$\begin{array}{l}\text { social interaction } \\
\text { (S) }\end{array}$} & greetings & $\begin{array}{l}\text { Greetings everyone, Wow, what a great } \\
\text { start to our forum today. As a moderator, I } \\
\text { welcome all of you to join this interesting } \\
\text { discussion, and don't hesitate to share your } \\
\text { opinion and thoughts! [Moderator 1: 1-4] }\end{array}$ \\
\hline & informal talk & $\begin{array}{l}\text { Hi Jen, how was your holiday? You must } \\
\text { be happy traveling back home after a long } \\
\text { time? [Moderator 2: 8-9] }\end{array}$ \\
\hline & $\begin{array}{l}\text { appreciating } \\
\text { and confirming } \\
\text { contributions }\end{array}$ & $\begin{array}{l}\text { Hi Ann, the definition given pertaining to } \\
\text { counselling is very interesting. Short and } \\
\text { simple. Excellent. I love it! [Olive: 13-15] }\end{array}$ \\
\hline & humour & $\begin{array}{l}\text { Please feel free to say your mind because I } \\
\text { can't bite you online, hehe! [Moderator 5: } \\
2-3 \text { ] }\end{array}$ \\
\hline & use emoticon/emojis & $\begin{array}{l}\text { Ara, what is your opinion in regard } \\
\text { to....... We can't wait to hear from you } \odot \\
\text { [Luke: } 12-15]\end{array}$ \\
\hline
\end{tabular}


Table 3 (Continued)

\begin{tabular}{|c|c|c|}
\hline Domains & Skills & Examples \\
\hline \multirow[t]{2}{*}{$\begin{array}{l}\text { sharing } \\
\text { information (K1) }\end{array}$} & providing opinion & $\begin{array}{l}\text { I totally agree with you that ICT usage help } \\
\text { counsellor communicate with their clients at } \\
\text { all time [Moderator 3:19-21] }\end{array}$ \\
\hline & asking questions & $\begin{array}{l}\text { However, have any of you done any } \\
\text { research on whether Malaysia has in } \\
\text { existence e-counselling service? How } \\
\text { do.......encourage e-counselling in } \\
\text { Malaysia?[Jen:12-16] }\end{array}$ \\
\hline \multirow[t]{4}{*}{$\begin{array}{l}\text { collaboration } \\
\text { (L1) }\end{array}$} & $\begin{array}{l}\text { coordination and } \\
\text { planning }\end{array}$ & $\begin{array}{l}\text { I see that our group only focuses on .... since } \\
\text { our discussion topic is.... so, any other ideas } \\
\text { on how...? [Moderator 5:34-36] }\end{array}$ \\
\hline & $\begin{array}{l}\text { summarizing } \\
\text { discussion }\end{array}$ & $\begin{array}{l}\text { We are heading to the end of the discussion, I } \\
\text { would like to conclude all the points } \\
\text { we had discussed [Moderator 7:26-29] }\end{array}$ \\
\hline & highlight contribution & $\begin{array}{l}\text { So, the point May is trying to tell us that... } \\
\text { am I right to say so? Can you rephrase.. } \\
\text { [Moderator 1:22-26] }\end{array}$ \\
\hline & $\begin{array}{l}\text { invite for team } \\
\text { collaboration }\end{array}$ & $\begin{array}{l}\text { What about you, Han, do you agree with the } \\
\text { opinion given by our friends? Maybe you can } \\
\text { share yours! [Sue: 6-7] }\end{array}$ \\
\hline \multirow[t]{3}{*}{$\begin{array}{l}\text { Egocentric } \\
\text { elaboration (K2) }\end{array}$} & giving feedback & $\begin{array}{l}\text { Since there are many disadvantages of } \\
\text { ICT, hence we as a counsellor, to add extra } \\
\text { information, we can also .... [Moderator } \\
5: 23-25]\end{array}$ \\
\hline & $\begin{array}{l}\text { adding personal } \\
\text { experiences/opinion }\end{array}$ & $\begin{array}{l}\text { I would like to add one more facility } \\
\text { available on the Internet whereby counsellor } \\
\text { can use software like Microsoft PowerPoint } \\
\text { to present their counselling material to be } \\
\text { more interactive [Thevi:18-20] }\end{array}$ \\
\hline & $\begin{array}{l}\text { introduce other } \\
\text { relevant information }\end{array}$ & $\begin{array}{l}\text { I think Joe's opinion on email security } \\
\text { needs more explanation. I don't think a big } \\
\text { company like Google would allow intruders } \\
\text { to access our data easily! [Moderator 4:26- } \\
27 \text { ] }\end{array}$ \\
\hline $\begin{array}{l}\text { Allocentric } \\
\text { elaboration (K3) }\end{array}$ & asking for elaboration & $\begin{array}{l}\text { However, for the telephone service do you } \\
\text { mean they talk through the phone? It would } \\
\text { be nicer for you in the future to elaborate } \\
\text { on.... [Moderator } 6: 24-26 \text { ] }\end{array}$ \\
\hline
\end{tabular}


Table 3 (Continued)

\begin{tabular}{|c|c|c|}
\hline Domains & Skills & Examples \\
\hline & providing judgment & $\begin{array}{l}\text { I agreed with Elvena opinion about..... } \\
\text { however, Tiresa and Maalini think in the } \\
\text { opposite way that..... in this situation, my } \\
\text { stands are...[Susie:16-18] }\end{array}$ \\
\hline & & $\begin{array}{l}\text { I like what you said previously, but I think } \\
\text { the theory you mention nothing related to.. } \\
\text { [Lim: 13-15] }\end{array}$ \\
\hline & $\begin{array}{l}\text { asking for clarification } \\
\text { and explanation }\end{array}$ & $\begin{array}{l}\text { It would be nice that someone can explain } \\
\text { the reason behind this.....[Moderator } 7 \text { : } \\
30-33]\end{array}$ \\
\hline \multirow[t]{2}{*}{$\begin{array}{l}\text { Application and } \\
\text { transfer (K4) }\end{array}$} & $\begin{array}{l}\text { playing devil's } \\
\text { advocate. }\end{array}$ & $\begin{array}{l}\text { I can see you feel that we should change } \\
\text { according to surrounding to upgrade } \\
\text { ourselves with technologies, however, have } \\
\text { ever if you wonder how one who does not } \\
\text { know to use a computer ever get online } \\
\text { counselling? So, do you still think that online } \\
\text { counselling is still conducive? [Moderator 1: } \\
27-30]\end{array}$ \\
\hline & & $\begin{array}{l}\text { Since online counselling is very possible, } \\
\text { schools should develop a platform to.... } \\
\text { the platform should be interactive and user } \\
\text { friendly.. [John:28-31] }\end{array}$ \\
\hline \multirow[t]{4}{*}{ Reflection (L2) } & archiving information & $\begin{array}{l}\text { In the previous discussion....., now can each } \\
\text { of you share your understanding from a } \\
\text { school perspective? [Moderator 4: 15-16] }\end{array}$ \\
\hline & constructive feedback & $\begin{array}{l}\text { I have noticed that all of you do not ... is } \\
\text { there any reasons why we are not looking } \\
\text { to...I would love us to focus more on... } \\
\text { [Moderator } 3: 13-18]\end{array}$ \\
\hline & self-evaluation & $\begin{array}{l}\text { I may not understand this correctly but } \\
\text { e-counseling in school should.... that is the } \\
\text { best solution [Amy:16-20] }\end{array}$ \\
\hline & promote self-regulation & $\begin{array}{l}\text { "I prefer to use interactive tools to } \\
\text { support... for example, lots of pictures on } \\
\text { the platform [Ray, 31-34] }\end{array}$ \\
\hline
\end{tabular}




\section{Relationship Among the Domains of Online Interactions}

Correlation analyses were performed to examine the relationship among different domains. The results indicate that $\mathrm{S}$ was significantly correlated with $\mathrm{K} 1, \mathrm{~K} 2, \mathrm{~K} 3$, and L2. K2 was significantly correlated K4 while K4 was significantly correlated with L1 and L2. No correlation was found between L2 and L3 with any other variables (see Table 4).
The results indicated that students with more social interaction were more likely to share information, elaborate their own arguments by comparing and contrasting peer multiple views. Knowledge constructed from elaborating, comparing, and synthesising led to an environment whereby students integrate new knowledge to prior learned knowledge to improve their understanding of specific content. Students' learning experiences also changed

Table 4

Correlation matrix of the knowledge construction patterns

\begin{tabular}{|c|c|c|c|c|c|c|c|c|}
\hline & $\mathrm{S}$ & $\mathrm{K} 1$ & $\mathrm{~K} 2$ & K3 & K4 & $\mathrm{L} 1$ & L2 & L3 \\
\hline $\begin{array}{l}\text { Social } \\
\text { Interaction } \\
\text { (S) }\end{array}$ & - & $1.000 * *$ & $.669 * *$ & $.632 * *$ & .285 & .101 & $-.548 * *$ & - \\
\hline $\begin{array}{l}\text { Sharing } \\
\text { information } \\
\text { (K1) }\end{array}$ & & - & $.669 * *$ & $.632 * *$ & .285 & .101 & $-.548 * *$ & - \\
\hline $\begin{array}{l}\text { Egocentric } \\
\text { elaboration } \\
(\mathrm{K} 2)\end{array}$ & & & - & -.025 & $.452 *$ & .367 & .030 & - \\
\hline $\begin{array}{l}\text { Allocentric } \\
\text { elaboration } \\
\text { (K3) }\end{array}$ & & & & - & -.175 & -.228 & $-.688 * *$ & - \\
\hline $\begin{array}{l}\text { Application } \\
\text { and transfer } \\
(\mathrm{K} 4)\end{array}$ & & & & & - & $.769 * *$ & $.457^{*}$ & \\
\hline $\begin{array}{l}\text { Coordination } \\
\text { (L1) }\end{array}$ & & & & & & - & $.514^{*}$ & - \\
\hline $\begin{array}{l}\text { Reflection } \\
\text { (L2) }\end{array}$ & & & & & & & - & - \\
\hline $\begin{array}{l}\text { Technical } \\
\text { Issues (L3) }\end{array}$ & & & & & & & & - \\
\hline
\end{tabular}

Note: $\quad *$ Correlation is significant at the 0.05 level (2-tailed)

** Correlation is significant at the 0.01 level (2-tailed) 
to self-regulated since in discussion forums students work as a team in planning, coordinating, and collaborating during the learning.

Throughout the semester, the e-moderation in the discussion forums had contributed to a significant increase in social interaction, knowledge construction at different levels from simply sharing facts, opinions, and experiences, to elaborating one's own or others' ideas, to applying and transferring knowledge in practices and finally regulate the collaborative learning processes.

These findings are consistent with those of past studies that e-moderators should display social interaction (greetings, jokes, and compliments) to create a pleasant and friendly climate which encourages participants to become involved (Sallán et al., 2010; Tirado et al., 2012;). Social presence is considered very important to motivate students to sustain the discussion in the forums as a fun and positive social learning environment promotes learning (Westerlaken et al., 2019).

Students who are comfortable with the platform and online environment are more actively involved in elaborations on concepts compared to passive students (Burhan-Horasanl1 \& Ortaçtepe, 2016; Chang \& Chang, 2014; Smet et al., 2008). The e-moderator ensures that everyone feels respected and values the opinions of others (Sallán et al., 2010; Salmon, 2002).

The e-moderator supports the discussion by considering others' ideas, asking for explanations, summarizing, comparing, and synthesizing multiple perspectives and encouraging active participation in mutual knowledge construction (Ghadirian et al., 2016; Xie \& Ke, 2011).

The e-moderation training had shown remarkable changes in students' knowledge construction as social interactions consistent with other studies (Oh et al., 2018; Ghadirian \& Ayub, 2017; Xie et al., 2010; Zhong \& Norton, 2019).

E-moderators keep forum discussions on track (Ghadirian et al., 2016; Martinho et al., 2014) by asking questions, rewriting the question when discussions are out of the subject, making clarification, and providing summaries of the discussion (Chen et al., 2019; Ng et al., 2009).

Students are more likely to evaluate their own learning in the discussion when the e-moderator provide feedback on their sharing. Positive feedback encouraged development of ideas that led to the negotiation of knowledge and understanding (Chen et al., 2019; Lai, 2015; Ng et al., 2009).

There were no significant results in terms of technical issues and technology problems, and assignment clarifications were not detected in the forum discussions.

\section{Differences in the Students' Interactions Patterns Before and After the Training for e-Moderation}

A null hypothesis was formulated based on the third research question:

$\mathrm{H}_{0}$ : There is no significant difference in student's interaction patterns before and after the training for e-moderation 
The skewness and kurtosis for prescore and post-score were examined as recommended in a small sample, values greater or less than 1.96 are sufficient to establish normality of the data (Ghasemi \& Zahediasl, 2012). The null hypothesis was rejected as there is no significant difference between the pre-score and post-score before and after the training for e-moderation (see Table 5). The $t$-test analysis showed there is a statistically significant difference in the pre-score $(M=1.10, S D=0.14)$ and post-score $(M=2.18, S D=0.54)$ with $t(23)=-11.646$, $p=0.000$. Therefore, the null hypothesis is rejected.

Thus, student's interaction quality improved after the e-moderation training. This indicates that the e-moderator training effectively developed students' e-moderating skills for knowledge construction.

Table 5

Paired Sample t-test for students' interaction pattern

\begin{tabular}{|c|c|c|c|c|c|c|}
\hline \multicolumn{7}{|c|}{ Paired Differences } \\
\hline & Mean & $\mathrm{N}$ & $\begin{array}{l}\text { Std. Deviation } \\
\text { (SD) }\end{array}$ & $\mathrm{t}$ & df & Sig. (2-tailed) \\
\hline $\begin{array}{l}\text { Pre-test } \\
\text { Post-test }\end{array}$ & $\begin{array}{l}1.10 \\
2.18\end{array}$ & $\begin{array}{l}24 \\
24\end{array}$ & $\begin{array}{l}0.14 \\
0.54\end{array}$ & -11.646 & 23 & .000 \\
\hline
\end{tabular}

Note: ${ }^{*} \mathrm{p}<0.05$

\section{CONCLUSIONS}

The overall results of this study imply that a skilled e-moderator can facilitate fruitful online discussions in forums. Even though the students in this study were novice users of the discussion forum and were also unfamiliar with online discussion and the collaborative process of learning, they did not seem to face many difficulties and managed to maintain an online presence.

The results more specifically indicate that e-moderator facilitation skills as such greetings, informal talk, appreciating and confirming contributions, humour, show continues support, adding facts, opinion, asking open-ended questions, bringing in other content information, elaborate and illustrating the contents with examples, personal views, and concepts, considering others' ideas, asking for content explanations and clarification, asking for summaries, comparing and synthesizing multiple perspectives, invite for further reflection, playing the devils' advocate, organizational arrangements and planning, provide constructive feedback and giving encouragement to promote self-regulated learning, had influenced students to sustain participation and interaction in the discussion forum. 
E-moderation training may be an effective strategy to support cognitive development in online discussions, support interaction of a collaborative task, promoting a sense of community among students, and eliciting more meaningful interactions. Hence, e-moderators training should be emphasized so that e-moderators can effectively facilitate discussions in online learning environments using specific skillsets which lead to developing knowledge, rather than just delivering knowledge, which often results in disappointing online discussions.

\section{ACKNOWLEDGEMENTS}

This work was supported by the UM-LiTER Research University Grant [RU002D-2016].

\section{REFERENCES}

Ain, N., Kaur, K., \& Waheed, M. (2016). The influence of learning value on learning management system use: An extension of UTAUT2. Information Development, 32(5), 1306-1321. doi:10.1177/0266666915597546

Asterhan, C. S. C., \& Schwarz, B. B. (2010). Online moderation of synchronous e-argumentation. International Journal of Computer-Supported Collaborative Learning, 5(3), 259-282. doi: 10.1007/s11412-010-9088-2

Biasutti, M. (2015). Creativity in virtual spaces: Communication modes employed during collaborative online music composition. Thinking Skills and Creativity, 17, 117-129. doi: 10.1016/j. tsc.2015.06.002

Biasutti, M. (2017). A comparative analysis of forums and wikis as tools for online collaborative learning. Computers and Education, 111, 158171. doi: 10.1016/j.compedu.2017.04.006
Bruner, J. (1966). Toward a theory of instruction. Cambridge, USA: Harvard University Press.

Brunings, R. H., Schraw, G. J., \& Ronning, R. R. (1990). Cognitive psychology and instruction (2nd ed.). Englewood Cliffs, USA: Merrill Prentice Hall.

Burhan-Horasanl1, E., \& Ortaçtepe, D. (2016). Reflective practice-oriented online discussions: A study on EFL teachers' reflection-on, in and for-action. Teaching and Teacher Education, 59, 372-382. doi: 10.1016/j.tate.2016.07.002

Carceller, C., Dawson, S., \& Lockyer, L. (2015). Social capital from online discussion forums: Differences between online and blended modes of delivery. Australasian Journal of Educational Technology, 31(2), 150-163. doi: 10.14742/ ajet. 1448

Chan, J., Hew, K., \& Cheung, W. (2009). Asynchronous online discussion thread development: Examining growth patterns and peer-facilitation techniques. Journal of Computer Assisted Learning, 25(5), 438-452. doi: 10.1111/j.1365-2729.2009.00321.x

Chang, J., \& Chang, S. (2014). Assessing peer support and usability of blogging in hybrid learning environments. Interactive Learning Environments, 22(1), 3-17. doi: 10.1080/10494820.2011.619889

Chen, Y., Lei, J., \& Cheng, J. (2019). What if online students take on the responsibility: Students' cognitive presence and peer facilitation techniques. Online Learning Journal, 23(1), 3761. doi: 10.24059/olj.v23i1.1348

Cho, M., \& Tobias, S. (2016). Should instructors require discussion in online courses? Effects of online discussion on community of inquiry, learner time, satisfaction, and achievement. International Review of Research in Open and Distance Learning, 17(2), 124-140. doi: 10.19173/irrodl.v17i2.2342 
Cohen, L., Manion, L., \& Morrison, K. (2011). Research methods in education. London, England: Routledge. Retrieved Jun 20, 2018, from https://books.google.com.my/ books?id=p7oifuW1 A6gC

De Wever, B., Keer, H ,Schellens, T., \& Valcke, M. (2010). Roles as a structuring tool in online discussion groups: The differential impact of different roles on social knowledge construction. Computers in Human Behavior, 26(4), 516-523. doi: 10.1016/j.chb.2009.08.008

De Wever, B., Schellens, T., Valcke, M., \& Van Keer, H. (2006). Content analysis schemes to analyze transcripts of online asynchronous discussion groups: A review. Computers and Education, 46(1), 6-28. doi: 10.1016/j.compedu.2005.04.005

DeWitt, D., Alias, N., Siraj, S., \& Hutagalung, F. (2014). Knowledge management in education : Designing instruction for using Wikis. In International conference on management and technology in knowledge, service, tourism \& hospitality (pp. 45-50). London, England: Taylor \& Francis Group. Retrieved Jun 10, 2018, from https://www.researchgate.net/ publication/300642164_Designing_instruction_ for_Knowledge_Management_processes_ using_a_wiki.

DeWitt, D., Alias, N., \& Md Nor, M. (2016). Student satisfaction in the use of online forums: A case study among undergraduates in a Malaysian public university. International Conference on Teaching and Learning in Higher Education (ICTL, 2016), Faculty of Education, University of Malaya, Kuala Lumpur, Malaysia.

DeWitt, D., \& Koh, E. (2020). Promoting knowledge management processes through an interactive virtual wall in a postgraduate business finance course. Journal of Education for Business, 95(4), 255-262. doi: 10.1080/08832323.2019.1635977

Ertmer, P. A., \& Koehler, A. A. (2015). Facilitated versus non-facilitated online case discussions:
Comparing differences in problem space coverage. Journal of Computing in Higher Education, 27(2), 69-93. doi: 10.1007/s12528015-9094-5

Fu, Q. K., \& Hwang, G. J. (2018). Trends in mobile technology-supported collaborative learning: A systematic review of journal publications from 2007 to 2016. Computers and Education, 119, 129-143. doi: 10.1016/j.compedu.2018.01.004

Gašević, D., Adesope, O., Joksimović, S., \& Kovanović, V. (2015). Externally-facilitated regulation scaffolding and role assignment to develop cognitive presence in asynchronous online discussions. Internet and Higher Education, 24, 53-65. doi: 10.1016/j.iheduc.2014.09.006

Ghadirian, H., Ayub, A., Bakar, K., \& Hassanzadeh, M. (2016). Growth patterns and e-moderating supports in asynchronous online discussions in an undergraduate blended course. International Review of Research in Open and Distributed Learning, 17(3), 190-208. doi: 10.19173/irrodl. v17i3.2397

Ghadirian, H., \& Ayub, A. F. M. (2017). Peer moderation of asynchronous online discussions: An exploratory study of peer e-moderating behaviour. Australasian Journal of Educational Technology, 33(1), 1-18. doi: 10.14742/ajet.2882

Ghasemi, A., \& Zahedias1, S. (2012). Normality tests for statistical analysis: A guide for non-statisticians. International Journal of Endocrinology and Metabolism, 10(2), 486-489. doi: 10.5812/ijem.3505

Gunawardena, C., Lowe, C., \& Anderson, T. (1997). Analysis of global online debate and the development of an interaction analysis model for examining social construction of knowledge in computer conferencing. Journal of Educational Computing Research, 17(4), 397-431.

Guzdial, M., \& Turns, J. (2000). Effective discussion through a computer-mediated anchored forum. 
Journal of the Learning Sciences, 9(4), 437-469. doi: 10.1207/S15327809JLS0904_3

Heo, H., Lim, K. Y., \& Kim, Y. (2010). Exploratory study on the patterns of online interaction and knowledge co-construction in project-based learning. Computers and Education, 55, 13831392. doi:10.1016/j.compedu.2010.06.012

Hew, F., \& Cheung, S. (2013). Audio-based versus text-based asynchronous online discussion: Two case studies. Instructional Sciences, 41(2), 365380. doi: 10.1007/s11251-012-9232-7

Hew, K. F. (2015). Student perceptions of peer versus instructor facilitation of asynchronous online discussions: Further findings from three cases. Instructional Science, 43(1), 19-38. doi: 10.1007/ s11251-014-9329-2

Hewitt, J. (2003). How habitual online practices affect the development of asynchronous discussion threads. Journal of Educational Computing Research, 28, 31-45. doi: 10.2190/PMG8-A05JCUH1-DK14

Hou, H., Wang, S., Lin, P., \& Chang, K. (2015). Exploring the learner's knowledge construction and cognitive patterns of different asynchronous platforms: Comparison of an online discussion forum and Facebook. Innovations in Education and Teaching International, 52(6), 610-620. doi: 10.1080/14703297.2013.847381

Hou, H., \& Wu, S. (2011). Analyzing the social knowledge construction behavioral patterns of an online synchronous collaborative discussion instructional activity using an instant messaging tool: A case study. Computers and Education, 57(2), 1459-1468. doi: 10.1016/j. compedu.2011.02.012

Jones, M., \& Ryan, J. (2014). Learning in the practicum: Engaging pre-service teachers in reflective practice in the online space. AsiaPacific Journal of Teacher Education, 42(2), 132-146. doi: 10.1080/1359866X.2014.892058
Kent, C., Laslo, E., \& Rafaeli, S. (2016). Interactivity in online discussions and learning outcomes. Computers and Education, 97, 116-128. doi: 10.1016/j.compedu.2016.03.002

Kim, D., Park, Y., Yoon, M., \& Jo, I. H. (2016). Toward evidence-based learning analytics: Using proxy variables to improve asynchronous online discussion environments. Internet and Higher Education, 30, 30-43. doi: 10.1016/j. iheduc.2016.03.002

Koh, J. H. L., Chai, C. S., Hong, H.-Y., \& Tsai, C.-C. (2014). A survey to examine teachers' perceptions of design dispositions, lesson design practices, and their relationships with technological pedagogical content knowledge (TPACK). Asia-Pacific Journal of Teacher Education, 2945(September), 1-14. doi: 10.1080/1359866X.2014.941280

Lai, K. (2015). Knowledge construction in online learning communities: A case study of a doctoral course. Studies in Higher Education, 40(4), 561579. doi: 10.1080/03075079.2013.831402

Lemke, J. L. (2001). Articulating communities: Sociocultural perspectives on science education. Journal of Research in Science Teaching, 38, 296316. doi: 10.1002/1098-2736(200103)38:3<296

Marbouti, F. (2012). Design, implementation and testing of a visual discussion forum to address new post bias (Master's thesis, Simon Fraser University, Vancouver, Canada). Retrieved April 22, 2018, from https://core.ac.uk/download/ pdf/56376356.pdf

Martinho, M., Almeida, P. A., \& Teixeira-Dias, J. (2014). Fostering students questioning through Moodle: Does it work? Procedia - Social and Behavioral Sciences, 116(iv), 2537-2542. doi: 10.1016/j.sbspro.2014.01.607

Ministry of Higher Education. (2015). Malaysia education blueprint 2015-2025 (higher education) 
(Vol. 2025). Putrajaya, Malaysia: Author. https:// doi.org/10.5923/j.ijis.20120206.05

Newman, R., Webb, B., \& Cochrane, C. (1995). A content analysis method to measure critical thinking in face-to-face and computer supported group learning. Interpersonal Computing and Technology, 3(2), 56-77.

Ng, C. S. L., Cheung, W. S., \& Hew, K. F. (2009). Sustaining asynchronous online discussions: Contributing factors and peer facilitation techniques. Journal of Educational Computing Research, 41(4), 477-511. doi: 10.2190/ EC.41.4.e

Noor, A. M., Attaran, M., \& Alias, N. (2015). Students' experiences in using spectrum: Textbook or classroom? Procedia - Social and Behavioral Sciences, 176, 667-673. doi: 10.1016/j.sbspro.2015.01.525

Oh, E. G., Huang, W.-H. D., Mehdiabadi, A. H., \& $\mathrm{Ju}$, B. (2018). Facilitating critical thinking in asynchronous online discussion: Comparison between peer- and instructor-redirection. Journal of Computing in Higher Education, 30(3), 489509. doi: 10.1007/s12528-018-9180-6

Orooji, F., \& Taghiyareh, F. (2015). Supporting participants in web-based collaborative learning activities from a holistic point of view: A tale of seven online and blended courses. Journal of Computers in Education, 2(2), 183-210. doi: 10.1007/s40692-015-0031-4

Park, J. Y. (2015). Student interactivity and teacher participation: An application of legitimate peripheral participation in higher education online learning environments. Technology, Pedagogy and Education, 24(3), 389-406. doi: 10.1080/1475939X.2014.935743

Rogoff, B. (1998). Cognition as a collaborative process. In D. Kuhn \& R. S. Siegler (Eds.),
Handbook of child psychology (5th ed., pp. 679744). New York, USA: Wiley.

Roscoe, R. D., \& Chi, M. T. H. (2007). Understanding tutor learning: Knowledge-building and knowledge-telling in peer tutors' explanations and questions. Review of Educational Research, 77(4), 534-574. doi: 10.3102/0034654307309920

Sallán, J. G., Gómez, D. R., \& Asparó, C. A. (2010). Who exactly is the moderator? A consideration of online knowledge management network moderation in educational organisations. Computers and Education, 55(1), 304-312. doi: 10.1016/j.compedu.2010.01.016

Salmon, G. (2002). Mirror, mirror, on my screen... Exploring online reflections. British Journal of Educational Technology, 33(4), 379-391. doi: 10.1111/1467-8535.00275

Salmon, G. (2012). E-moderating: The key to online teaching and learning (3rd ed.). New York, USA: Routledge.

Salmon, G. (2013). E-tivities: The key to active online learning (2nd ed.). New York, USA: Routledge.

Schellens, T., \& Valcke, M. (2006). Fostering knowledge construction in university students through asynchronous discussion groups. Computers and Education, 46(4), 349-370. doi: 10.1016/j.compedu.2004.07.010

Schökler, G. (2015). Integrating personality in e-moderating - A discussion from the perspective of practical experience. The Journal of Teaching English For Specific and Academic Purposes, 3(3), 457-465.

Sloan, C. (2015). The relationship of high school student motivation and comments in online discussion forums. Journal of Educational Computing Research, 52(1), 114-135. doi: $10.1177 / 0735633114568857$

Smet, M., Keer, H., Wever, B., \& Valcke, M. (2010). Cross-age peer tutors in asynchronous discussion 
groups: Exploring the impact of three types of tutor training on patterns in tutor support and on tutor characteristics. Computers and Education, 54(4), 1167-1181. doi: 10.1016/j. compedu.2009.11.002

Smet, M., Keer, H., \& Valcke, M. (2008). Blending asynchronous discussion groups and peer tutoring in higher education: An exploratory study of online peer tutoring behaviour. Computers and Education, 50(1), 207-223. doi: 10.1016/j. compedu.2006.05.001

So, H.-J., \& Brush, T. A. (2008). Student perceptions of collaborative learning, social presence and satisfaction in a blended learning environment: Relationships and critical factors. Computers \& Education, 51(1), 318-336. doi: 10.1016/j. compedu.2007.05.009

Sun, Z., Lin, C. H., Wu, M., Zhou, J., \& Luo, L. (2018). A tale of two communication tools: Discussion-forum and mobile instant-messaging apps in collaborative learning. British Journal of Educational Technology, 49(2), 248-261.doi: 10.1111/bjet.12571

Thormann, J., Gable, S., Fidalgo, P. S., \& Blakeslee, G. (2013). Critical thinking, and Social Network Analysis (SNA) in online courses. The International Review of Research in Open and Distance Learning, 3(3), 294-318.

Tirado, R., Hernando, Á., \& Aguaded, J. I. (2012). The effect of centralization and cohesion on the social construction of knowledge in discussion forums. Interactive Learning Environments, 23(3), 293316. doi: 10.1080/10494820.2012.745437

Tseng, J.-J., Lien, Y.-J., \& Chen, H.-J. (2016). Using a teacher support group to develop teacher knowledge of Mandarin teaching via web conferencing technology. Computer Assisted Language Learning, 29(1), 127-147. doi: 10.1080/09588221.2014.903978
Viera, A., \& Garrett, J. (2005). Understanding interobserver agreement: The Kappa statistic. Family Medicine, 37(5), 360-363.

Vygotsky, S. (1978). Mind in society: The development of higher psychological processes. Cambridge, USA: Harvard University Press.

Wei, H. C., Peng, H., \& Chou, C. (2015). Can more interactivity improve learning achievement in an online course? Effects of college students' perception and actual use of a course-management system on their learning achievement. Computers and Education, 83, 10-21. doi: 10.1016/j. compedu.2014.12.013

Weinberger, A., Ertl, B., Fischer, F., \& Mandl, H. (2007). Epistemic and social scripts in computersupported collaborative learning. Instructional Science: An International Journal of Learning and Cognition, 33(1), 1-30. doi: 10.1007/s11251004-2322-4

Wertsch, V. (1998). Mind as action. New York, USA: Oxford University Press.

Westerlaken, M., Christiaans-Dingelhoff, I., Filius, R. M., De Vries, B., De Bruijne, M., \& Van Dam, M. (2019). Blended learning for postgraduates; An interactive experience. BMC Medical Education, 19(1), 1-7. doi: 10.1186/s12909-019-1717-5

Xie, K. (2013). What do the numbers say? the influence of motivation and peer feedback on students' behaviour in online discussions. British Journal of Educational Technology, 44(2), 288301. doi: 10.1111/j.1467-8535.2012.01291.x

Xie, K., \& Ke, F. (2011). The role of students' motivation in peer-moderated asynchronous online discussions. British Journal of Educational Technology, 42(6), 916-930. doi: 10.1111/j.14678535.2010.01140.x

Xie, Y., Ke, F., \& Sharma, P. (2010). The effects of peer-interaction styles in team blogs on students' 
cognitive thinking and blog participation. Journal of Educational Computing Research, 42(4), 459-479.

Yang, S. H. (2016). Conceptualizing effective feedback practice through an online community of inquiry. Computers and Education, 94, 162177. doi: 10.1016/j.compedu.2015.10.023

Yang, Y. T. C., Gamble, J., \& Tang, S. Y. S. (2012). Voice over instant messaging as a tool for enhancing the oral proficiency and motivation of English-as-a-foreign-language learners. British Journal of Educational Technology, 43(3), 448464. doi: 10.1111/j.1467-8535.2011.01204.x

Yeh, H.-T., \& Lahman, M. (2007). The qualitative report pre-service teachers' perceptions of asynchronous online discussion on blackboard. The Qualitative Report, 12(4), 680-704. Retrieved Jan 10, 2016, from http://nsuworks. nova.edu/tqr\%5Cnhttp://nsuworks.nova.edu/ tqr/vol12/iss4/9
Zhong, Q. M., \& Norton, H. (2019). Exploring the roles and facilitation strategies of online peer moderators. Studies in Self-Access Learning Journal, 10(4), 379-400. doi: 10.37237/100405

Zumbrunn, S., Tadlock, J., \& Roberts, E, D. (2011). Encouraging self-regulated learning in the classroom: A review of the literature. Metropolitan Educational Research Consortium (MERC), Virginia Commonwealth University, 36(5), 403-406. doi: 10.1007/s10643-009-0305-4 
